\title{
A Review of Ethical Leadership Practice and Corporate Social Responsibility Approach during COVID-19
}

Christine Reidhead*

Navajo Technical University, Lowerpoint Rd State Hwy 371, Crownpoint, NM 87313, United States

DOI: $10.36347 /$ sjebm.2020.v07i09.006

| Received: 14.09.2020 | Accepted: 22.09.2020 | Published: 25.09.2020

*Corresponding author: Christine Reidhead

Abstract

Review Article

The current COVID situation has brought some serious ethical dilemmas and challenges for employers who are acting in leadership roles. Different companies responded in different ways to contribute within their allowed capacity to stand strong against the economic and humanitarian crisis. This paper begins with exploring the changing role of CSR during COVID times and inferred that its focus is shifting towards the idea of conscious capitalism and stakeholder relationship management. With that, it reinforces the articulation of authentic CSR which is required for a sustainable business model after the crisis is over. Next, it emphasized the importance of CSR in the COVID times as it enables companies to secure high consumer and employee loyalty and trust levels which contributes somehow towards the economic growth of the company for a long-term basis. Then, it analyzed the role of ethical leadership in light of the COVID situation to see if it can add to the CSR effectiveness. It was argued that customer orientation encourages ethical leaders to not compromise their ethical standards while regarding the whole community-wide perspective. Finally, the value of having a strong responsible culture was discussed which can generate more impactful CSR outcomes.

Keywords: Ethical leadership, Corporate Social Responsibility, CSR, COVID-19, conscious capitalism, responsible corporate culture.

Copyright @ 2020: This is an open-access article distributed under the terms of the Creative Commons Attribution license which permits unrestricted use, distribution, and reproduction in any medium for non-commercial use (NonCommercial, or CC-BY-NC) provided the original author and source are credited.

\section{INTRODUCTION}

The COVID-19 crisis is not like any other crisis that businesses have witnessed before. Many companies stepped up to help their communities by facilitating health facilities with financial donations, employing their production chains to make virus combatting products and by getting products and machinery for the protection from the virus [1]. Some other actions included providing support for remote work, financial help in urgent cases and training opportunities to the employees. All these activities come under the Corporate Social Responsibility (CSR) strategy to take immediate effective actions and serve the community needs. It was not an easy step for companies to make this commitment due to the challenges presented by the COVID outbreak. Somehow, CSR at this time ruled out many other strategic decisions of businesses as a result of its proven differentiation and importance to focus on benefiting the greater community by creating shared value for all the stakeholders.

In recent papers, researchers also focused their attention on configuring some effective CSR strategies to apply while aligning it with the business agenda. With that, it was repeatedly addressed in the past literature that CSR can only be effectively managed under strong leadership. In this time, companies face a very competitive leadership challenge and it is important to identify the right leadership style that can make the most effective strategic choices for the company's CSR management programs. As leadership styles are taken to be context-specific so our prediction is based on the positive impact of ethical leadership on CSR to be effective by all means in the context of the pandemic. Prior research shows that ethical leadership has a positive impact on CSR implementation. In a book written by Idowu, Vertigans \& Schiopoiu [2], some case studies were also presented to reveal the effectiveness of ethical leadership on CSR in managing crisis situations.

Previous studies have focused on evaluating CSR and the impact of ethical leadership in various contexts. Darnell [3] investigated the effectiveness of CSR to counter negative publicity and improve firm reputation under strong ethical leadership. Zhang \& Borden [4] gauged the impact of issue-related CSR 
programs on stakeholders' perception of issue related crisis and the results indicated that such programs can help in improving the perceived corporate credibility. However, CSR development under the impact of ethical leadership has not been explored in the pandemic context. The current crisis situation has affected every other business unit and not just anyone in particular. Previous studies showed that with every huge impact crisis moment, there is always a very important development in the CSR domain. Through this study, we aim to analyze the shift in focus of CSR in the light of this novel context and identify ways to make it more effective when faced with a global level crisis through ethical leadership in a responsible corporate culture.

\section{Changing role of CSR during COVID}

The current pandemic situation has led many companies to recognize the importance of CSR more than ever. The overall corporate response around the world towards CSR has considerably been affirmative, but that was mostly from large or global corporations who had the feasible potential to invest their resources and profits to respond to the COVID situation. Having said that, they were also compelled to compromise on some aspects like some were reported to lay off their employees even though employees' welfare should have been on top of their CSR prior activities in the first place. A renowned Business website compiled a list of companies who opted for downsizing of their employees which included Coca Cola, Ford, NBC Universal, Daimler, LinkedIn, IMB and the list goes on as a reaction to COVID-19 situation [5]. This shows how much these companies cared for their most valued stakeholders in times of crisis and their level of resilience to counter the crisis situation. Apparently, these famous companies were resilient enough, yet they were still unable to completely serve their employees if not other stakeholders to maintain a certain level of their profitability and growth through this period.

Looking at the pre-COVID landscape of CSR, many researchers earlier debated on this notion that businesses took it more as a PR item to add to their brand's image building or a mere voluntary contribution to play a part in the community, meaning that they were not very much invested in authentic CSR. Those companies that linked their CSR activities with their business model to become more sustainable added value in achieving sustainability-related goals to some extent who gave it a serious effort. [6] But as of now, a lot of other companies are still struggling hard while facing the consequences of the COVID situation and that can be attributed to the reason that they didn't put real effort in the CSR domain earlier in normal times as most of them dedicated their compliance owing to the reason of imposition of regional laws regarding sustainability-related measures. However, the focus of CSR and the priorities that went along changed as a result of COVID situation. Now, the changing role of CSR is evolving with its focus and purpose inclining towards the progression of social sustainability and conscious capitalism as a lesson learned from the current scenario that businesses must hone their responsibility of providing both profit and non-profit based benefits to all of their stakeholders. A lot of significant change in businesses' attitude towards CSR is presumed to occur to counter the effects of the current situation in the future.

The concept of conscious capitalism has been covered by some of the past researches already and the current times further reinforce the importance of that concept, especially the responsibility towards the welfare of employees has been widely studied in all the recent papers of business and marketing. While studying the strategic view of CSR in the era of conscious capitalism, CSR creates a more sustainable model of the businesses if they follow conscious capitalism where businesses set ethical standards in all of their operations and involve the interests of the stakeholders [6]. Adding to that, such companies can have a better social perceived reputation and increased brand value for a longer term. Initially, CSR was highly crucial in building perceived a brand reputation in front of all the stakeholders, but that intention alone carries businesses attention away from authentic CSR and from standing as a socially responsible brand in its original meaning. The question here arises that at what level of authenticity will the businesses pursue a CSR based sustainable model to fulfill social responsibility in the post-COVID era? This answer can only be judged after the crisis is over and researchers must further explore this area in light of some empirical evidence.

On the contrary, a study stated a viewpoint that businesses are less likely to invest in CSR since they are struggling for their short term survival at this stage which is a true case [7]. Total CSR spends of the companies can presumably be reduced depending on the level of impact on profitability and how much impact that business is ready to accept in these times. Yet, we foresee that the current situation has awakened businesses to the reality that CSR is not limited to what companies see it as a branding strategy and it is essential for serving the interests of their stakeholders which include employees, consumers, suppliers, other business partners and communities. Hence, this might encourage them to invest in CSR since the relationship with stakeholders needs to be strengthened more than ever now as they have the power to influence the economic activity of the company. Ebrahim \& Buheji [8] proposed a COVID centric CSR initiatives model to ensure stronger communities, economies and capacities where it also outlined a point to maintain a trustworthy relationship with the stakeholders. It again directs towards the idea of conscious capitalism that also works to serve the needs of the stakeholders. 
Another recent paper critically discussed the details of CSR while drawing the comparison between both developed and developing countries in times of a crisis situation [9]. It mentioned that the recent development in CSR as a result of COVID situation further emphasized the provision of remote employment of workers in both the developing and developed countries. This shows that CSR actions are not just to attract customers or serve the purpose of the shareholders, but it actually starts with supporting the employees within an organization. For a forceful impact, relevant CSR actions need to be taken that are close to business activities not just for a limited time, but which can be sustained for many years to come. This way, businesses can stay more consistent and effective with their CSR practices and use their position of power to develop a circular economy.

\section{Role of ethical leadership in CSR during COVID}

The impact of ethical leadership has been investigated in recent studies and it is considered to be an effective leadership form that can positively influence the CSR activities and its associated outcomes. Speaking of the current COVID period, companies need to play an active role in the community where they must demonstrate their responsibility towards their community and other core stakeholders. This responsibility is effectively fulfilled when ethical leaders lead the way. Tian, Liu \& Fan [10] mentioned that CSR implementation is strengthened under higher ethical leadership and greater external stakeholder pressure. This shows that ethical leaders can better guide and fulfil the CSR mandate in the crisis situation. The foremost action we believe ethical leaders must take in CSR during this unprecedented period is to safeguard their employees' comfort and safety by providing flexibility at work. Flexible companies at this time are better responding to COVID situation than those that are not flexible. Yet, it is a challenging ordeal considering that these companies are struggling with their operational continuity and financial resilience while at the same time, they are reaching out to support the most vulnerable in this humanitarian and economic crisis.

A paper investigated the roles of leadership styles in CSR and found that transformational leadership is positively related to institutional CSR practices which results in positive organizational outcomes [11]. Transformational leadership is almost close to ethical leadership as they regard the importance of ethical standards and values which are demonstrated through the decisions that lead the actions in CSR related matters. These set of ethical values preached by ethical leaders do not change from one context to another, hence we presume that ethical leaders respond the same in both crisis and normal situations. Such responsible leadership can prevent companies from falling prey to unethical practices. Besides, Kim \& Thapa [12] indicated that the firm's operational performance can be enhanced by ethical leadership style which also helps to promote CSR activities.

All the more, a strong relationship maintenance with stakeholders is also believed to be taken as a top priority by ethical leaders for social accountability. This happens in those organizations that serve a higher purpose rather than generating profits and revenue for the business. Ethical leaders promote CSR along with stakeholder relationship management as it helps in building the credibility of the organization on CSR stance [13]. Also, ethical leaders take it as a way to increase the trust and loyalty of both their customers and employees. Another point worth noting is that it is important to first take care of internal stakeholders to ensure the effective implementation of CSR practices as the outcome of these practices will serve to support the external stakeholders. Here, ethical leadership is significantly needed to keep the employee engagement high by communicating the purpose in the right manner. Ethical leadership has a direct impact on employee's CSR engagement which builds their strong commitment towards CSR values [14]. Besides, ethical leaders have the power to boost the morale of the employees which further helps to improve their productivity levels and drive their sense of commitment to work for the common social good.

This period is a demanding phase for all the ethical leaders who have to make critical and quick decisions in this situation of uncertainty while keeping it fair and transparent. They have to find the right balance between making profits for the company and taking ethical decisions while the stakes are high. But the recent shift towards community orientation in these times is what can encourage the ethical leaders to not think of short term business interests. With that, the appeal to moral principles is strong at this stage so leaders have a greater reason to take a long-term and community wide perspective. Four important values that we identify for ethical leaders at this time are empathy, transparency, commitment and expertise to win the trust of stakeholders. The measure of the impact of these values can have some sort of effect on the decision-making of the ethical leaders. Donthu \& Gustafsson [1] stressed the focus of businesses towards authentic CSR after examining the development of CSR and marketing in the current pandemic context. We predict that the stronger these values of ethical leaders are, the more likely they act towards generating value in the CSR outcomes which as a result creates a shift more towards authentic CSR.

\section{CSR linked with responsible corporate culture and ethical leadership}

Modern customers are conscious customers who expect businesses to give value being in strong economic positions to the community they serve. Those businesses serve the community through their CSR programs that require both ethical leadership and a 
responsible work climate to form an organizational vision through which social progress can be promoted in the form of organizational policies and procedures. A strong and responsible corporate culture is critical for the success of any business where all the actions are conducted in light of certain values and principles that are a part of internal workplace policies [15]. To create this culture, ethical leadership then enforces those values like transparency, accountability, integrity and fairness. These values propagate the purpose of CSR practices within and outside the organization.

In light of the pandemic context, the responsible corporate culture is somehow useful in engaging the employees to work towards the cause of common good in the CSR department. It also gives them a sense of purpose to work diligently in this tough period. Ethical leaders are there to inspire them to make their way through this time and cooperate with the firm. $\mathrm{Li}, \mathrm{K}$ et al., [16] proved that corporate culture is an important asset in making the firms resilient to the pandemic. Hence, if a culture of responsibility is not created in these troubled times, then the firms will less likely focus on their approach towards CSR.

Those companies that will be reconsidering their approach towards CSR in the post-COVID period must think of forming more responsible cultures to advocate CSR values. Trivellas, $\mathrm{P}$ et al., [17] studied that CSR is positively linked with Organizational commitment which is directly related to organizational performance. Since CSR impact is linked somehow with the performance of the company, the CSR activities involved must also be tracked with related metrics. This can be used to check the similar impact and contribution to the economic prosperity, quality of the environment and the social capital. Those companies that contribute greatly to these shows a high level of investment in CSR. It reflects the real effort to invest in purpose-driven CSR other than just displaying cosmetic actions to be in good eyes of the public

Both responsible culture and ethical leadership have a direct relation with the CSR impact on social and environmental systems. In order to have a strong CSR impact, it is important to have strong ethical leadership and a strong ethical corporate culture that creates an enabling environment so necessary steps can be taken to navigate the path of crisis management. Previously, the relationship of CSR, ethical leadership and organizational performance has been evaluated in the researches, but the relation of culture and ethical leadership with CSR impact combined have not yet been explored. This relationship requires empirical evidence to study how much both contribute in the development of CSR impact.

\section{CONCLUSION}

In light of this review, companies must take on a shift from a standard business approach to a communal mindset in their CSR approach during this COVID period to create a strong impact being an active community member as opposed to being a business entity that is solely operating to make a profit for the company's shareholders. Companies with strong CSR must have both ethical leadership and a responsible corporate culture so they can contribute to economic prosperity, quality of the environment, and the social capital with a greater effect. Companies that will invest in CSR are more likely to sustain through this period by gaining the support and trust of the stakeholders. With that, this paper reinforces the idea that community orientation and conscious capitalism is the way forward in CSR under the ethical leadership guidance in the COVID period.

\section{REFERENCES}

1. Donthu N, Gustafsson A. Effects of COVID-19 on business and research. Journal of Business Research. 2020; 117:284-289.

2. Idowu S, Vertigans S, Schiopoiu Burlea A. Corporate Social Responsibility in Times of Crisis. Cham: Springer International Publishing; 2017.

3. Darnell J. Corporate Social Responsibility and Firm Reputation Risk: Bettering Firm Reputational Risk through Socially Responsible Activities. SSRN Electronic Journal. 2017.

4. Zhang X, Borden J. Linking Issue Management, Corporate Social Responsibility and Crisis Communication: Applying Balance Theory in Crisis and Issue Management. 2020.

5. The coronavirus outbreak has triggered unprecedented mass layoffs and furloughs. Here are the major companies that have announced they are downsizing their workforces. [Internet]. Business Insider. 2020 [cited 14 September 2020]. Available

from: https://www.businessinsider.com/coronaviruslayoffs-furloughs-hospitality-service-travelunemployment-2020\#ibm-will-eliminate-severalthousand-jobs-as-of-may-22-mainly-in-thecompanys-technology-services-division-cutscome-a-month-after-new-ceo-arvind-krishnawithdrew-ibms-financial-outlook-amid-economicuncertainty-caused-by-the-pandemic-32

6. Ahen F, Zettinig P. Critical perspectives on strategic CSR: what is sustainable value cocreation orientation?. Critical perspectives on international business. 2015;11(1):92-109.

7. He H, Harris L. The impact of Covid-19 pandemic on corporate social responsibility and marketing philosophy. Journal of Business Research. 2020;116:176-182.

8. Ebrahim A, Buheji M. A Pursuit for a 'Holistic Social Responsibility Strategic Framework' Addressing COVID-19 Pandemic Needs [Internet]. Article.sapub.org. 2020 [cited 14 
September 2020]. Available from: http://article.sapub.org/10.5923.j.economics.20201 005.04.html

9. Popkova E, DeLo P, Sergi B. Corporate Social Responsibility Amid Social Distancing During the COVID-19 Crisis: BRICS vs. OECD Countries. 2020.

10. Tian Q, Liu Y, Fan J. The effects of external stakeholder pressure and ethical leadership on corporate social responsibility in China. Journal of Management \& Organization. 2015;21(4):388410.

11. Du S, Swaen V, Lindgreen A, Sen S. The Roles of Leadership Styles in Corporate Social Responsibility [Internet]. Academia.edu. 2020 [cited 14 September 2020]. Available from: https://www.academia.edu/6068788/The_roles_of _leadership_styles_in_corporate_social_responsbil ity

12. Kim M, Thapa B. Relationship of Ethical Leadership, Corporate Social Responsibility and Organizational Performance. Sustainability. 2018;10(2):447.
13. De Roeck K, Farooq O. Corporate Social Responsibility and Ethical Leadership: Investigating Their Interactive Effect on Employees' Socially Responsible Behaviors. Journal of Business Ethics. 2017;151(4):923-939.

14. Nejati M, Salamzadeh Y, Loke C. Can ethical leaders drive employees' CSR engagement?. Social Responsibility Journal. 2019;16(5):655669.

15. Choi S, Ullah S, Kwak W. Ethical Leadership and Followers' Attitudes Toward Corporate Social Responsibility: The Role of Perceived Ethical Work Climate. Social Behavior and Personality: an international journal. 2015;43(3):353-365.

16. Li K, Liu X, Mai F, Zhang T. The Role of Corporate Culture in Bad Times: Evidence from the COVID-19 Pandemic. SSRN Electronic Journal. 2020.

17. Trivellas $\mathrm{P}$, Rafailidis A, Polychroniou $\mathrm{P}$, Dekoulou P. Corporate social responsibility (CSR) and its internal consequences on job performance. International Journal of Quality and Service Sciences. 2019;11(2):265-282. 